Available online at https://jurnal.stmikroyal.ac.id/index.php/jurdima

\title{
PEMBINAAN BLOGGING PADA MASYARAKAT SEKUPANG BATAM KEPULAUAN RIAU
}

\author{
Pastima Simanjuntak $^{* 1}$, Erlin Elisa ${ }^{2}$, Nurma Dhona Handayani ${ }^{3}$ \\ ${ }^{1}$ Teknik Informatika, Universitas Putera Batam \\ ${ }^{2}$ Sistem Informasi, Universitas Putera Batam \\ ${ }^{3}$ Sastra Inggris, Universitas Putera Batam \\ email:*p.lastria@gmail.com
}

\begin{abstract}
Along with advances in information technology that is increasingly changing and encouraging various efforts to change, where the Sei Harapan Sekupang community is still unfamiliar with information and communication technology, many people, especially school children and adolescents who still do not understand the application of information technology in the field of blogging and also still lack of understanding of the application of ICT, especially applications that are on the computer, therefore the purpose of this coaching is to invite the Sei Harapan community to find out the use of information technology in the field of Blogging. This blogging coaching is also to find out the latest technology and information that is currently growing rapidly including blogging and know the benefits of information technology development in the field of blogging so that the public can be motivated to evaluate and learn information technology in the field of blogging as a basis for learning and to support various activities in daily life are included in online sales activities using blogs, and are accustomed to using information technology tools appropriately and optimally to obtain and process information in learning, working and other activities so that the community is able to be creative, develop imaginative attitudes, develop independent exploration capabilities , and easy to adapt to new developments in the environment.
\end{abstract}

Keywords: Coaching, Training, Applications, Blogging

\begin{abstract}
Abstrak: Seiring dengan kemajuan teknologi informasi yang semakin mengalami perubahan dan mendorong berbagai usaha perubahan, dimana masyarakat Sei Harapan Sekupang masih awam tentang teknologi informasi dan komunikasi, banyaknya masyarakat khususnya anakanak sekolah dan remaja yang masih belum paham akan penerapan teknologi informasi dibidang blogging dan juga masih kurang paham akan penerapan TIK khususnya aplikasi yang ada di komputer, maka dari itu tujuan pembinaan ini mengajak masyarakat Sei Harapan untuk mengetahui pemanfaatan teknologi informasi dibidang Blogging. Pembinaan blogging ini juga untuk mengetahui teknologi dan informasi terbaru yang saat ini berkembang dengan pesat termasuk blogging dan mengetahui manfaat perkembangan teknologi informasi dibidang blogging sehingga masyarakat dapat termotivasi untuk mengevaluasi dan mempelajari teknologi informasi dibidang blogging sebagai dasar untuk belajar dan untuk mendukung berbagai aktifitas dalam kehidupan sehari-hari termasuk dalam hal aktivitas penjualan secara online dengan menggunakan blog, dan terbiasa menggunakan perangkat teknologi informasi secara tepat dan optimal untuk mendapatkan dan memproses informasi dalam kegiatan belajar, bekerja, dan aktifitas lainnya sehingga masyarakat mampu berkreasi, mengembangkan sikap imaginatif, mengembangkan kemampuan eksplorasi mandiri, dan mudah beradaptasi dengan perkembangan baru di lingkungannya.
\end{abstract}

Kata kunci: Pembinaan, Pelatihan, Aplikasi, Blogging 
Available online at https://jurnal.stmikroyal.ac.id/index.php/jurdima

\section{PENDAHULUAN}

Pesatnya kemajuan teknologi tidak bisa dipungkiri semakin memanjakan manusia, contohnya dalam hal berkomunikasi. Interaksi yang terjadi dengan adanya bantuan teknologi menjadi semakin mudah dan beragam (Idrus, 2014). Teknologi informasi menyatukan komputasi dan komunikasi berkecepatan tinggi untuk data, suara, dan video.

Teknologi informasi dan komunikasi mencakup dua aspek yaitu teknologi informasi dan teknologi komunikasi. Teknologi informasi meliputi segala hal yang berkaitan dengan proses, penggunaan sebagai alat bantu, manipulasi, dan pengelolaan informasi (Simanjuntak, dkk., 2019). Sedangkan teknologi komunikasi adalah segala sesuatu yang berkaitan dengan penggunaan alat bantu untuk memproses dan mentransfer data dari perangkat yang satu ke lainnya. Oleh karena itu, teknologi informasi dan teknologi komunikasi adalah dua buah konsep yang tidak terpisahkan. Teknologi informasi dan komunikasi mengandung pengertian luas yaitu segala kegiatan yang terkait dengan pemrosesan, manipulasi, pengelolaan, pemindahan informasi antar media.

Permasalahan di tempat pembinaan ini adalah masih banyaknya masyarakat di daerah Sei Harapan Sekupang ini yang belum mengetahui cara untuk memanfaatkan aplikasi komputer khususnya aplikasi blogging, bahkan banyak masyarakat ini yang memang belum mengenal sama sekali pengunaan dari Blogging, dan yang mereka ketahui hanya cara menjalankan yang sederhana saja. Oleh karena itu dibutuhkan pembinaan yang bisa dilakukan selama satu bulan untuk membina mereka dalam memanfaatkan pembuatan blogging.

Tujuan dari kegiatan pembinaan ini adalah 1) Memberikan pembinaan dan pelatihan pada masyarakat khususnya anak-anak Sekolah dan Remaja dari Tingkat SD, SMP sampai SMA dapat dan terbiasa menggunakan perangkat teknologi informasi secara tepat dan optimal dan pelatihan pem- buatan email. 2)Memberikan pembinaan pada masyarakat khususnya anak-anak Sekolah dan Remaja dari Tingkat SD, SMP sampai SMA untuk pemanfaatan teknologi informasi dibidang blogging untuk mendapatkan dan memproses informasi dalam kegiatan belajar, bekerja, dan mengembangkan bisnis yang mereka miliki dengan memasarkan lewat blog yang dibuat.

\section{METODE}

Waktu pelaksanaan pengabdian ini adalah dua kali pertemuan selama bulan Agustus 2018. Setiap pengabdi memiliki waktu dua kali pertemuan untuk memberikan pembinaan. Sesuai dengan waktu yang ditetapkan oleh Lembaga Penelitian dan Pengabdian Kepada Masyarakat. Adapun tempatnya adalah di Sei Harapan RT 006 RW VI, Kecamatan Sekupang, Kota Batam, Kepulauan Riau.

Metode pelaksanaan kegiatan terdiri dari 3 tahapan pelaksaaan antara lain sebagai berikut: 1)Tahap Persiapan dengan melakukan survey ke Sei Harapan RT 006 RW VI. 2) Tahap Pelaksanaan dengan melalukan pembinaan dan pelatihan selama satu bulan mengenai penggunaan dan pemanfaatan dari blogging. 3) Tahap Akhir dengan kegiatan observasi dan evaluasi. Observasi dilakukan terhadap masalah yang muncul dalam proses pembautan blogging. Evaluasi dilakukan terhadap penggunaan dan pemanfaaatan dari blogging.

\section{PEMBAHASAN}

Pengabdian dilaksanakan selama dua hari, pengabdian ini dilakukan dimulai dari 06 Agustus dan 07 Agustus 2018, dan Pengabdian yang bertempat di Kantor Kelurahan Masyarakat Sei Harapan Sekupang berjalan dengan lancar dan kondusif. Peserta yang hadir sebanyak 18 orang yang terdiri dari para remaja dan beberapa masyarakat di Kelurahan tersebut. Peserta pengabdian di Kelurahan Sei Harapan ini bisa mengikuti pembinaan dengan baik dengan materi 
Available online at https://jurnal.stmikroyal.ac.id/index.php/jurdima

mengenai penggunan teknologi dan Pembuatan blogging yang disampaikan. tim pengabdi yang melaksanakan pengabdian terdiri atas tiga orang yakni dua dosen dan satu mahasiswa. Pada laporan pengabdian ini, tim pengabdi melakukan pembinaan mengenai pengantar teknologi informasi dan pembuatan blogging kepada para peserta saja dan berharap para peserta ini dapat menjadikan materi sebagai informasi yang penting untuk diketahui. Kegiatan pembinaan ini dimaksudkan untuk memberikan tambahan wawasan dan ilmu pengetahuan kepada para peserta pengabdian sekaligus membimbing mereka.

Pemanfaatan teknologi informasi sangat berguna dalam pembinaan pengadian di Sei Harapan. Adapun Perangkat Komputer dapat diartikan sebagai sekumpulan benda atau alat yang bekerja menurut fungsinya masingmasing dalam sebuah komputer untuk mencapai sebuah hasil dari komputer tersebut. Selesai memperkenalkan komponenkomponen komputer tim pengabdi di hari kedua memperkenalkan teknologi dan informasi. Seperti komputer, laptop, kalkulator, internet, camera digital, TV dan lain-lain.

Pengabdian hari pertama dan hari kedua, pengabdi melakukan kegiatan pembinaan tentang penjelasan mengenai teknologi informasi, pembuatan email dan dilanjutkan dengan pembuatan blogging dan masyarakat Sei Harapan sangat bersemangat dengan pembinaan yang sedang berlangsung sampai selesai dilaksanakan di tempat itu.

Kegiatan pengabdian masyarakat yang telah dilakukan oleh tim pengabdi yakni memberikan pembinaan kepada masyrakat Sei Harapan, Sekupang, Kota Batam, Kepulauan Riau ini yaitu menjelaskan perangkat komputer dan cara membuat blog. Pembinaan yang dilakukan supaya masyarakat di Sei Harapan mengenal akan teknologi informasi dan Bisa membuat blog untuk masingmasing pribadi yang dibutuhkan dalam kehidupan sehari-hari.

Target luaran kegiatan pengabdian yang dilakukan mengenai Pembinaan pembuatan blogging adalah para masyrakat Sei Harapan mampu memahami, mengerti dan bisa mem- buat blog masing-masing untuk menunjang semua keperluan yang dibutuhkan masyarakat Sei Harapan. Pengenalan perangkat teknologi memudahkan masyarakat untuk lebih mengenal akan pentingnnya teknologi informasi serta fungsi dari teknologi informasi tersebut. Contohnya Microsoft Office yang merupakan software application yang paling mudah dipahami serta paling mudah untuk dipelajari sehingga dapat dipergunakan untuk membantu masyarakat Sei Harapan dalam hal penyampaian informasi seperti para perangkat RT RW yang mau mempresentasikan kegiatan mereka di Sei Harapan ke Luar Kota. Dengan pengabdian dalam bentuk pembinaan yang kami lakukan, kami harapkan masyarakat Sei Harapan sedikit banyaknya bisa mengerti apa yang sudah dilakukan oleh tim pengabdi.

Hasil dari kegiatan pembinaan ini adalah menunjukkan bahwa para masyarakat Sei Harapan paham akan pemanfaatkan teknologi informasi dan pembuatan blog sehingga masyarakat bisa mengerri dan memanfaatkannya dengan baik.

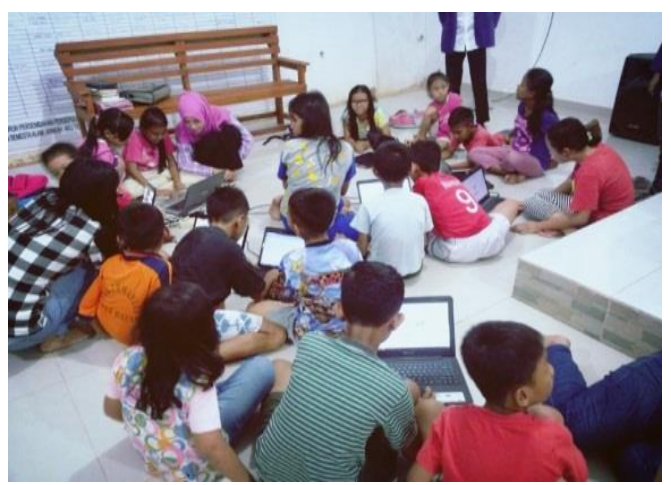

Gambar 1. Pelatihan Aplikasi Bloging

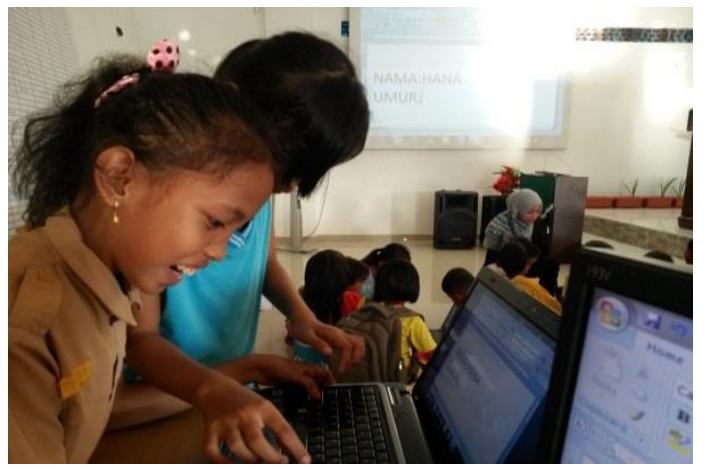

Gambar 2. Praktek Aplikasi Bloging 


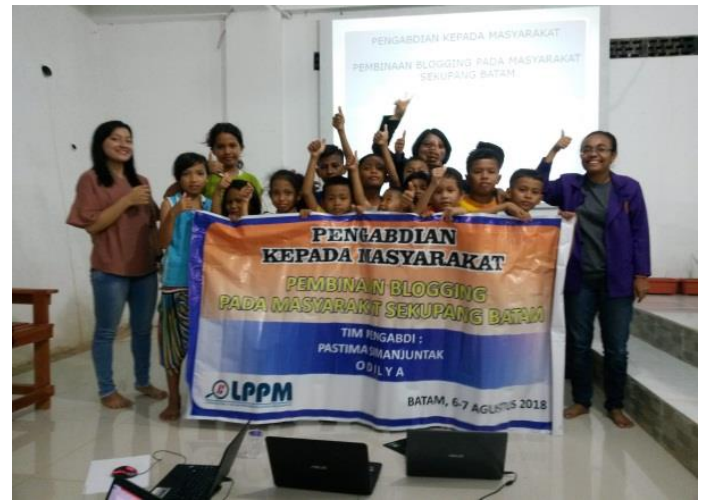

Gambar 1. Dokumentasi Kegiatan PKM

\section{SIMPULAN}

Dari kegiatan pengabdian yang dilakukan oleh tim pengabdi di Sei Harapan sekupang Batam dapat disimpulkan sebagai berikut:

1. Masyarakat Sei Harapan sudah mengenal dan mengetahui manfaat dari perangkat teknologi informasi.

2. Masyarakat Sei Harapan bisa membuat email.

3. Masyarakat Sei Harapan bisa membuat blog.

4. Dengan memberikan pembinaan kepada masyarakat Sei Harapan, pengabdi memperkenalkan perangkat komputer, perangkat teknologi informasi dan pelatihan pembuatan blog sehingga bisa mendorong masyarakat bisa lebih mengerti akan teknologi informasi.

Adapun saran dari kegiatan pembinaan pada masyarakat Sei Harapan, Kecamatan Sekupang, Kota Batam, Kepulauan Riau adalah sebagai berikut:

1. Bagi pengurus RT/RW di Kelurahan Sei Harapan sebaiknya membuat program pelatihan peningkatan pemanfaatan teknologi informasi dan blogging agar perencanaan, proses dan evaluasi pemerintahan yang dihasilkan dapat mencapai tujuan yang diharapkan.

2. Bagi masyarakat Sei Harapan harus mengembangkan diri terhadap kemampuan penguasaan teknologi in- formasi, sehingga pemanfaatan teknologi informasi dapat berjalan dengan baik sesuai dengan tujuan yang ingin dicapai.

\section{UCAPAN TERIMA KASIH}

Penulis mengucapkan terimakasih kepada RT/RW Sei Harapan Sekupang, Teman dosen Univesitas Putera Batam dan LPPM Universitas Putera Batam yang sudah memberikan dukungan untuk pelaksanaan kegiatan pengabdian kepada masyarakat ini dengan baik.

\section{DAFTAR PUSTAKA}

Ali Idrus, (2014) 'Pemanfaatan Teknologi Informasi Dan Komunikasi Dalam Layanan Administrasi Akademik Terhadap Peningkatan Kinerja Di SMA Negeri Kota Jambi', Tekno-Pedagogi, Vol 4 No 2, 20-31.

LPPM. 2018. Panduan Pengabdian kepada Masyarakat Universitas Putera Batam. LPPM UPB Batam.

Simanjuntak, P., Handoko, K. (2019) 'Pembinaan Pemanfaatan Teknologi Informasi Dan Komunikasi Pada Masyarakat Pulau Temoyong Batam Kepulauan Riau', Jurnal Matappa, Vol 2 No 1, 20-23.

Simanjuntak, P., Realize., Handoko, K. (2019) 'Pembinaan Administrasi Dan Dokumentasi Dengan Memanfaatkan Software Application', Jurdimas, Vol 2 No2, 132-136. 